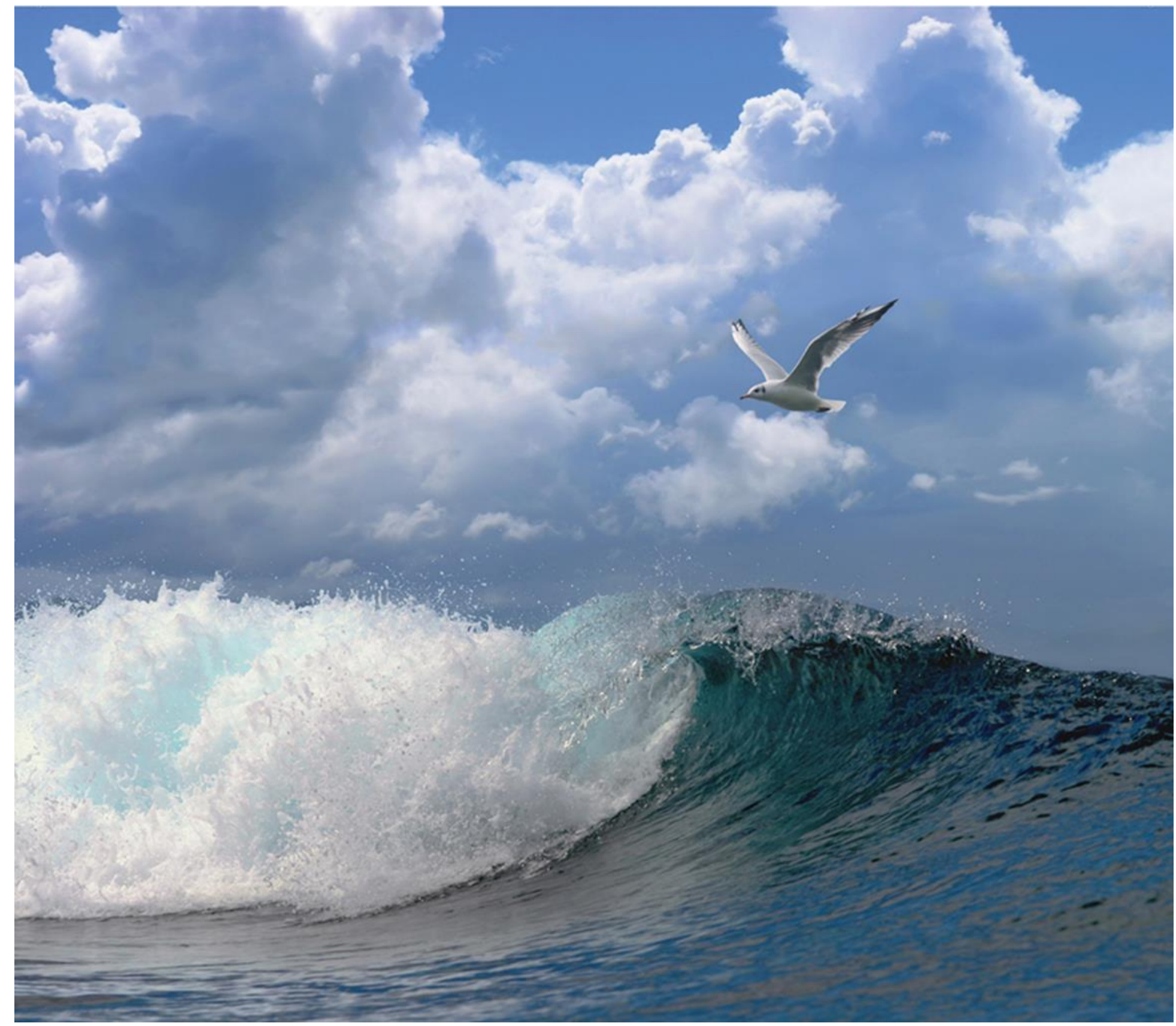

\title{
Ecologisch Gericht Suppleren: Meetplan kustlangse survey 2019
}




\section{Ecologisch Gericht Suppleren: Meetplan kustlangse survey 2019}

Auteur(s): $\quad$ Ralf van Hal 
Keywords: kustzone, kraamkamer, juveniele vis, zandsuppletie

Opdrachtgever: RWS-WVL, hoogwaterveiligheid

T.a.v.: Petra Damsma

Postbus 17

8200 AA Lelystad

Dit rapport is gratis te downloaden van https://doi.org/10.18174/477940

Wageningen Marine Research verstrekt geen gedrukte exemplaren van rapporten.

Wageningen Marine Research is ISO 9001:2015 gecertificeerd.

(C) Wageningen Marine Research

Wageningen Marine Research, instituut binnen de rechtspersoon Stichting

Wageningen Research, hierbij

vertegenwoordigt door Dr. M.C.Th.

Scholten, Algemeen directeur

KvK nr. 09098104,

WMR BTW nr. NL 8113.83.696.B16.

Code BIC/SWIFT address: RABONL2U

IBAN code: NL 73 RABO 0373599285
Wageningen Marine Research aanvaardt geen aansprakelijkheid voor gevolgschade, noch voor schade welke voortvloeit uit toepassingen van de resultaten van werkzaamheden of andere gegevens verkregen van Wageningen Marine Research opdrachtgever vrijwaart Wageningen Marine Research van aanspraken van derden in verband met deze toepassing.

Alle rechten voorbehouden. Niets uit deze uitgave mag weergegeven en/of gepubliceerd worden, gefotokopieerd of op enige andere manier gebruikt worden zonder schriftelijke toestemming van de uitgever of auteur. 


\section{Inhoud}

$\begin{array}{lr}\text { Samenvatting } & 4\end{array}$

$1 \quad$ Inleiding $\quad 5$

1.1 Achtergrond $\quad 5$

1.2 Eerdere werkzaamheden in 2016, 2017 en $2018 \quad 7$

1.3 Kustlangse survey in $2019 \quad 8$

$\begin{array}{ll}1.4 & \text { Randvoorwaarden }\end{array}$

2 Methode $r$

2.1 Meetstrategie $\quad 10$

2.1.1 Doelsoorten vis 10

$\begin{array}{ll}2.1 .2 & \text { Temporele dekking } \\ 2.1 .3 & \text { Ruimtelijke dekking }\end{array}$

$\begin{array}{ll}2.1 .3 & \text { Ruimtelijke dekking } \\ & 10\end{array}$

2.1.4 Biotische en abiotische habitatvariabelen 11

$\begin{array}{ll}2.1 .5 & \text { Bemonsteringsinstrumenten } \\ \end{array}$

2.2 Meetplan 12

2.2.1 Visbemonstering $\quad 12$

2.2.2 Vangstverwerking $\quad 12$

$\begin{array}{ll}2.2 .3 \text { CTD } & 13\end{array}$

$\begin{array}{lll}2.2 .4 & \text { Secchi } & 13\end{array}$

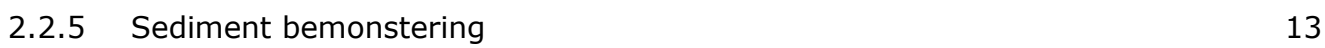

$\begin{array}{ll}2.2 .6 & \text { Personele inzet }\end{array}$

$\begin{array}{ll}\text { 2.2.7 Databeheer en -management } & 14\end{array}$

$3 \quad$ Kwaliteitsborging $\quad 15$

$\begin{array}{lr}\text { Literatuur } & 16\end{array}$

$\begin{array}{lr}\text { Verantwoording } & 17\end{array}$ 


\section{Samenvatting}

Suppleties van zand op vooroever of strand worden in opdracht van Rijkswaterstaat uitgevoerd om de Nederlandse kust tegen erosie te beschermen en om voldoende zand in het kustfundament te houden. Een groot deel van de suppleties vindt plaats in of nabij de kuststrook die binnen de Natura2000 regelgeving wordt beschermd, de Noordzeekustzone. Het is dus van belang de eventuele effecten van deze praktijk op de natuur zorgvuldig te bestuderen, zodat dit effect kan worden afgezet tegenover het algemene nut voor de maatschappij. Betere kennis van de effecten kan leiden tot beperking van eventuele schade aan- en mogelijk zelfs tot versterking van- gewenste natuurwaarden en ecosysteemdiensten. Tot nog toe is er in vergelijking met benthos relatief weinig aandacht geweest voor de gevolgen van suppleren op vispopulaties, terwijl de kinderkamerfunctie van de ondiepe kustzone voor vis een zeer belangrijke economische ecosysteemdienst levert. Kennis van de omgevingsfactoren die het voorkomen van juveniele vis in de ondiepe kustzone bepalen, leidt tot een verbeterd inzicht in de gevolgen van suppleties op vispopulaties en daarvan afhankelijk zeeleven.

In overleg met natuurorganisaties en de kennisinstituten Deltares en Wageningen Marine Research is in 2016 het document 'Ecologische effecten van zandsuppleties' (Herman et al., 2016) geschreven met als doel onderzoek te formuleren naar ecologische effecten van zandsuppleties. In het onderdeel 'uitvoeringsplan' (deel C in Herman et al. 2016) zijn 3 onderzoekslijnen (ook wel Krachtlijnen genoemd) gedefinieerd, te weten: Vooroever, Duinen en Waddenzee. Het hier beschreven meetplan voor een survey in 2019 valt onder de onderzoekslijn Vooroever. De onderzoeksvraag luidt: "Wat zijn de cumulatieve gevolgen van reguliere suppleties op samenstelling en functioneren van het ecosysteem van de ondiepe vooroever van de Nederlandse kust?" Deze volgt uit de prioritering van de krachtlijn Vooroever: (cumulatieve) gevolgen van reguliere suppleties op samenstelling en functioneren van het ecosysteem van de vooroever.

De werkzaamheden in 2019 zijn aanvullend op de gegevens verzameld in 2017 en 2018 in de ondiepe vooroever $(<10 \mathrm{~m})$. In deze voorgaande jaren kon het programma niet in zijn geheel uitgevoerd worden vanwege de weersomstandigheden, met name de bemonstering van de ondiepste zone $(<1 \mathrm{~m})$ was een probleem. De bemonstering van de ondiepste zone is nu een apart programma (van der Geest e.a., 2019). En voor de diepere zone wordt uitsluitend de bemonstering van demersale vis in relatie tot het sediment voorgesteld, waarbij een kustlangse bemonstering inzicht moet geven in de ruimtelijke verspreiding van demersale vis. Voor deze aanpak is het onderzoeksschip de Luctor één week beschikbaar in juni. In deze week zal er vanuit Stellendam gestart worden met het bemonsteren van vis op een diepte van 5-6 m, waarbij noordwaarts langs de kust gewerkt wordt en om de 1,5-2 $\mathrm{km}$ een locatie bemonsterd zal worden. Als de tijd het toelaat, zal er op een enkele locatie een aantal monsters naar dieper water genomen worden, wat inzicht moet geven in eventuele effecten van diepte op de samenstelling van de demersale vispopulatie. 


\section{$1 \quad$ Inleiding}

\subsection{Achtergrond}

Suppleties van zand op vooroever of strand worden in opdracht van Rijkswaterstaat uitgevoerd om de Nederlandse kust tegen erosie te beschermen en om voldoende zand in het kustfundament te houden. Deze strategie wordt sinds enige decennia in Nederland toegepast en bestrijdt en voorkomt op effectieve wijze erosie van de zandige kust, zodat deze voldoende bescherming biedt en ruimte biedt aan diverse functies (Mulder e.a., 2011).

Een groot deel van de suppleties vindt plaats in of nabij de kuststrook die binnen de Natura2000 regelgeving wordt beschermd, de Noordzeekustzone. Het is dus van belang de eventuele effecten van deze praktijk op de natuur zorgvuldig te bestuderen, zodat dit effect kan worden afgezet tegenover het algemene nut voor de maatschappij. Betere kennis van de effecten kan ook helpen om gerichte aanpassingen te identificeren welke kunnen leiden tot het beperken van eventuele schade aan- en mogelijk zelfs tot versterken van- gewenste natuurwaarden en ecosysteemdiensten door suppletie. Bij de Zandmotor bijvoorbeeld worden additionele ecosysteemdiensten gecreëerd zoals ruimte voor recreatie, rust- en foerageerlocaties voor vogels en een uitbreiding van het grondwater aquifer ten behoeve van drinkwaterwinning. Ook in andere kustsystemen worden natuurlijke oplossingen voor kustveiligheid gecombineerd met de versterking van natuur en ecosysteemdiensten (Temmerman e.a., 2013; Van Slobbe e.a., 2013; De Vriend e.a., 2015).

Rijkswaterstaat is opdrachtgever voor een meerjarig onderzoeksprogramma Ecologisch Gericht Suppleren II/Natuurlijk Veilig. In overleg met natuurorganisaties en de kennisinstituten Deltares en Wageningen Marine Research is in 2016 het document 'Ecologische effecten van zandsuppleties' (Herman e.a., 2016) geschreven met als doel onderzoek te formuleren naar ecologische effecten van zandsuppleties. In het onderdeel 'uitvoeringsplan' (deel C in Herman e.a. (2016)) zijn drie onderzoekslijnen (ook wel Krachtlijnen genoemd) gedefinieerd, te weten: Vooroever, Duinen en Waddenzee.

De onderzoeksvraag die in dit meetplan wordt behandeld volgt uit de prioritering van de Krachtlijn Vooroever van het onderzoeksprogramma Ecologisch Gericht Suppleren II: (Cumulatieve) gevolgen van reguliere suppleties op samenstelling en functioneren van het ecosysteem van de vooroever. Herman e.a. (2016) schrijven op p.70:

\section{(Cumulatieve) gevolgen van reguliere suppleties op samenstelling en functioneren van het ecosysteem van de vooroever}

Allereerst blijkt uit de beschrijving van kennisvragen in hoofdstuk 3 dat er veel vragen liggen over de cumulatieve effecten van suppleties op de fysische en ecologische processen van de vooroever. Hierbinnen liggen verschillende vragen met een fysische koppeling, bijvoorbeeld over de rol van de korrelgrootte voor benthos en vis, de lange termijneffecten van suppleties op het sorteringsmechanisme, de relatie tussen bankendynamiek en benthos. Daarnaast liggen er verschillende vragen over ecologische processen zoals over voedselwebinteracties en het belang van de vooroever voor vis. Vanwege het brede spectrum aan vragen wat er ligt op het gebied van de lange en middellange termijneffecten van suppleties op de ecologie van vooroever en de samenhang tussen deze vragen, wordt er voorgesteld om hier het zwaartepunt te leggen binnen het aankomend onderzoek. Hoewel wij voorstellen verschillende onderdelen van het kustsysteem een substantieel deel te laten uitmaken van het aankomende programma, behoeft het beantwoorden van genoemde vragen over de vooroever een sterke monitoringscomponent. Gezien het criterium "haalbaarheid tijd en budget" zal er daarom een keuze in het zwaartepunt gemaakt moeten worden. 
De onderzoeksvraag voor het programma luidt: "Wat zijn de cumulatieve gevolgen van reguliere suppleties op samenstelling en functioneren van het ecosysteem van de ondiepe vooroever van de Nederlandse kust?". De vraag richt zich op reguliere suppleties, op de middellange termijn en op de ruimtelijke schaal van regio's van de Nederlandse kust, die mogelijk veranderingen veroorzaken in de benthische fauna, de visfauna en de kinderkamerfunctie van de ondiepe vooroever voor juveniele vis. Tevens onderzoekt het programma of die eventuele effecten voorspelbaar zijn, en ontwikkelt daarvoor het instrumentarium. Deze krachtlijn werkt met een aantal hypothesen die zijn samengevat op p. 74 van Herman e.a. (2016):

- $\quad$ Regelmatige suppleties leiden tot een verandering van fysische karakteristieken in het habitat, met name korrelgrootteverdeling, steilheid van de vooroever, diepte en bankendynamiek, waardoor de gemeenschappen in de jaren na suppletie niet terugkeren naar de uitgangssituatie maar naar een gewijzigde samenstelling die in overeenstemming is met de gewijzigde fysische habitatkarakteristieken. Dit geldt zowel voor benthos als vis.

- De vooroever is van groot belang voor de ontwikkeling van vispopulaties, omdat hij als kinderkamer fungeert. Veranderingen in de kinderkamerfunctie van de vooroever hebben een significant effect op de populaties, ook al treden ze slechts op in een ruimtelijk beperkte fractie van het verspreidingsgebied van de (adulte) populatie.

- Er zijn ruimtelijke gradiënten in de habitats van de vooroever langs de Nederlandse kust, van Zeeland tot de Waddenzee, die zich reflecteren in de samenstelling van de gemeenschappen van benthos en vis, en die de gevoeligheid van deze gemeenschappen voor suppleties beïnvloeden. Gradiënten kunnen scherp zijn bij geulen en buitendelta's en door deze landschapselementen worden bepaald. Een betere habitatclassificatie verbetert de voorspelbaarheid van effecten van (herhaalde) suppleties.

De kinderkamerfunctie van de ondiepe kustzone voor juveniele vis is van groot ecologisch belang voor vispopulaties en daarvan afhankelijk zeeleven, en levert daarnaast een belangrijke economische ecosysteemdienst met betrekking tot de visserij. Herman e.a. (2016) schrijven op p. 63:

Vispopulatie in de vooroever

Vispopulaties hebben een groot verspreidingsgebied, waarvan de vooroever slechts een beperkt deel is. Populatie-effecten van suppletie zijn slechts te verwachten als de kuststrook een buitenproportioneel groot belang heeft voor de populatie als geheel of tijdens een bepaald deel van de levenscyclus, zoals het geval kan zijn voor de kinderkamerfunctie van juveniele vis (Teal en van Keeken, 2011). Dit belang van de vooroever voor vis moet worden onderzocht in het kader van de ontwikkeling van de gehele populatie. Een verkennende aanpak middels habitatgeschiktheidsmodellering is als eerste stap gezet (Glorius e.a., 2012; van de Wolfshaar e.a., 2012), waarmee een opmaat is gegeven naar populatiedynamische modellering zoals in van de Wolfshaar e.a. (2015), maar deze benaderingen zijn beperkt in hun toepasbaarheid omdat te weinig veldgegevens over voorkomen van vis in de kustzone beschikbaar zijn. Deze modellering is een methodiek om vast te stellen of fysische veranderingen in de relatief nauwe kuststrook relevant zijn voor vispopulaties en dus visserij, of niet. Claims dat suppleties een negatief effect hebben op de ontwikkeling van vispopulaties in de Nederlandse kustwateren, moeten kritisch worden onderzocht. Hiervoor is het van belang dat het voorkomen van vis (niet alleen bodemsoorten maar ook pelagische soorten), en in het bijzonder juveniele vis, in de vooroever wordt onderzocht in relatie met overige parameters zoals benthos (als voedsel), sedimentsamenstelling, morfologie en dynamiek (reactie vis op suppleties).

Ter beantwoording van de onderzoeksvraag is in het plan van aanpak (Herman e.a., 2016) voorgesteld om (onder andere) een survey uit te voeren in de vooroever (0-12 m diepte) langs de gehele Nederlandse kust, waarbij benthos, vis en habitatkarakteristieken worden meegenomen. Zo'n bemonstering bleek praktisch niet uitvoerbaar, waardoor er gekozen is om een intensieve bemonstering uit te voeren in een beperkt aantal kustgebieden. De selectie van deze gebieden was in eerste instantie gebaseerd op de verwachtte sedimentsamenstelling om hierin de maximale variatie te bemonsteren en daarnaast op basis van de praktische mogelijkheden (Baptist e.a., 2017). De uitvoering van deze bemonsteringen in 2017 en 2018 is belemmerd door beschikbaarheid van het 
onderzoeksschip en de weersomstandigheden, waardoor niet alle gegevens verzameld konden worden. Daarnaast blijkt de koppeling van de tegelijk verzamelde gegevens lastiger en minder informatief dan was verwacht.

In 2019, wordt de flexibiliteit in de planning van de bemonstering wederom beperkt door de beschikbaarheid van het onderzoeksschip, wat ook dit jaar het onderzoek in de vooroever erg afhankelijk maakt van de weersomstandigheden tijdens de beschikbare vaartijd. Op basis van de verwachting maar een deel van het programma te kunnen uitvoeren en de beperkte toegevoegde waarde van het tegelijkertijd verzamelen van alle gegevens is er besloten om in tegenstelling tot voorgaande jaren de bemonstering in 2019 anders in te richten.

De bemonstering van de ondiepste zone $(<1 \mathrm{~m})$, welke het meest afhankelijk is van het weer, is nu een zelfstandige bemonstering geworden waardoor deze flexibeler uitgevoerd kan worden. Voor deze ondiepste zone is voor 2019 een strandbemonstering opgezet die in maart 2019 van start is gegaan en zal lopen tot eind juni 2019 (van der Geest e.a., 2019). Tijdens deze strandbemonstering wordt de vestiging en opgroei van met name jonge platvis gevolgd over de tijd door om de 2 à 3 weken te monsteren. Hierbij is de verwachting dat met name schol (Pleuronectes platessa) zich vestigt in de brandingszone. Naar mate deze schol groter wordt, trekt deze van de ondiepe brandingszone naar dieper water. Eind van de zomer, begin najaar wordt deze 0-groep schol aangetroffen in de zone $>10$ $\mathrm{m}$ tijdens de reguliere langjarige vissurveys (BTS en DFS). Voor de tussenliggende periode is het zo goed als onbekend hoe de verspreiding van 0-groep schol en andere jonge vis is de kustzone is. De bemonsteringen in 2017 en 2018 hebben laten zien dat er in het gehele gebied van strand tot $10 \mathrm{~m}$ diep jonge vis voorkomt in juni-juli (van Hal e.a., 2017; van Hal en Dijkman Dulkes, 2018). Hierbij werden de hoogste aantallen aangetroffen op een diepte van 5-6 m, al is dit door het gebruik van verschillende bemonsteringsmethodes (4-10 m Luctor, 1-4 m rubberboot; <1 m lopend) lastig aan te tonen.

Om inzicht in de ruimtelijke verspreiding van juveniele vis in de ondiepe kustzone in het voorjaar te verkrijgen, wordt er aanvullend op de strandbemonstering een kustlangse bemonstering in de zone 5$6 \mathrm{~m}$ voorgesteld. Tijdens deze survey zal naast demersale vis een beperkter aantal omgevingsvariabelen bemonsterd worden dan in 2017 en 2018. Er zal nu geen infauna, pelagische vis en zoöplankton verzameld gaan worden. De tijdwinst die dit oplevert zal gebruikt worden om in een groter gebied dan in voorgaande jaren de verspreiding van juveniele vis in kaart te brengen.

Dit rapport beschrijft de meetstrategie, de meetmethoden, de te meten variabelen (vis, macrobenthos (uit de boomkorvangsten) en omgevingsvariabelen) en de bemonsteringslocaties voor deze kustlangse bemonstering in 2019.

\subsection{Eerdere werkzaamheden in 2016, 2017 en 2018}

De ondiepe kustzone is nog niet vaak bestudeerd vanwege de slechte toegankelijkheid. Het is snel te ondiep voor schepen, maar te diep om te kunnen lopen. Schepen die hier wel kunnen bemonsteren zijn doordat ze niet diep in het water liggen gevoelig voor golven, die zich hier snel ontwikkelen. Om ervaring op te doen met gecombineerd toepassen van diverse bemonsteringstechnieken in ondiepe kustwateren is er een pilot bemonstering uitgevoerd in 2016. De belangrijkste bevindingen van de pilot survey (Couperus e.a., 2017) zijn samengevat in Baptist e.a. (2017).

Op basis van de bevindingen in deze pilot is in 2017 de geïntegreerde ecosysteem survey ingericht waarbij niet de gehele kust, maar vier vooraf geselecteerde kustvakken (Zuid-Holland, Noord-Holland, Texel en Ameland) langs de Nederlandse kust zijn bemonsterd. De selectie van deze vier gebieden was in eerste instantie gebaseerd op de verwachtte sedimentsamenstelling om hierin de maximale variatie te bemonsteren en daarnaast op basis van de praktische mogelijkheden (Baptist e.a., 2017). Deze kustvakken zijn kenmerkend voor de Nederlandse kustregio's Hollandse kust en Waddenkust. In ieder van deze vier gebieden werden raaien met zeven monsterlocaties van strand tot 10 meter diepte gepland. Deze monsterlocaties werden vervolgens bemonsterd voor vis: boomkor, zegen en akoestisch; voor benthos en sediment: steekbuizen, boxcore en 3d-stereocamera; voor zoöplankton: WP2-net; en voor omgevingsvariabelen: CTD, Secchi-schijf en multimeter. Pelagisch vissen ter ondersteuning van de akoestische gegevens is niet uitgevoerd omdat het onderzoeksschip Luctor niet kon worden aangepast om dit te faciliteren.

In 2017 (12 juni t/m 7 juli) zijn alle vier de kustvakken bemonsterd (van Hal e.a., 2017), maar vanwege de weersomstandigheden zijn de gebieden Texel en Ameland niet volledig bemonsterd. Met 
name in het gebied Ameland zijn de ondiepste stations in zijn geheel niet bemonsterd. In 2018 (18 t/m 22 juni) is een kustvak (Schiermonnikoog) bemonsterd (van Hal en Dijkman Dulkes, 2018), de geplande monsterposities overlapten deels met eerdere bemonstering uitgevoerd binnen EGS1 (Van Dalfsen e.a., 2014; Damsma e.a., 2017). Vanwege weersomstandigheden konden de ondiepste stations niet bemonsterd worden, deze zijn op 27 juni vanaf het strand alsnog bemonsterd.

\section{$1.3 \quad$ Kustlangse survey in 2019}

De randvoorwaarde voor het veldwerk voor 2019 en 2020 bestaat uit één week waarin de Luctor beschikbaar is voor onderzoek. Deze week is al lang van tevoren vastgelegd en kan niet worden aangepast wanneer de weersomstandigheden ongunstig zijn. Gezien de ervaringen in 2017 en 2018, is er een groot risico dat de weersomstandigheden beperkend gaan zijn tijdens die week. Om dit risico te verminderen, is een aanpassing van het veldwerk voorgesteld.

De bemonstering van de ondiepste kustzone $(<1 \mathrm{~m})$, welke het meest weersafhankelijk is, is nu losgekoppeld van de bemonstering van de dieper gelegen vooroever en als een apart meetplan beschreven (van der Geest e.a., 2019). Daarnaast wordt de focus verlegd van het bemonsteren van raaien in een beperkt gebied waarbij veel omgevingsvariabelen worden verzameld, naar het bemonsteren van vis op één diepte (5-6 m) in een groter gebied waarbij minder omgevingsvariabelen worden verzameld. Zodoende kunnen er in de beperkte vaartijd meer locaties worden bemonsterd. Er is gekozen voor het monsteren op 5-6m diepte, omdat op deze diepte de hoogste concentratie jonge vis werd gevangen tijdens de 2017 bemonstering.

Er wordt nu het volgende voorgesteld:

- $\quad$ Kustlangse survey op één diepte (5-6 m).

- Vanaf Zuid-Holland zover mogelijk noordwaarts.

- Langs de zandmotor (vergelijking met de bemonstering 2017 en de gegevens van het zandmotor project)

- Langs Katwijk (waar de strandbemonstering 2019 wordt uitgevoerd)

- Langs Castricum (waar de strandbemonstering 2019 wordt uitgevoerd en in 2017 is bemonsterd)

- Waarbij gevist wordt met het DFS-bodemtuig (vergelijkbaar met 2017+2018)

- Aantallen vis en macrobenthos per soort

- Lengte van de vissen per soort

- Sediment genomen wordt met een happer (sneller, makkelijker en iets minder weersafhankelijk dan de boxcore)

- Korrelgrootte van het sediment

- Waarbij CTD en doorzicht gemeten wordt

Aangezien Yerseke de thuishaven is van de Luctor, wordt er gekozen om vanuit zuid naar noord te werken, om zo efficiënt mogelijk gebruik te kunnen maken van de beschikbare vaartijd. De toezegging is dat de Luctor op maandagochtend vanuit Stellendam de werkzaamheden kan gaan uitvoeren, waardoor starten net buiten de haven van Stellendam het hoogste aantal monsterpunten oplevert. Het buiten Stellendam beginnen met monsteren, maakt het ook mogelijk om een eventueel gradiënt in juveniele vis waar te nemen vanaf de Voordelta langs de Nederlandse kust richting Waddenzee. Tijdens het noordwaarts bemonsteren wordt er verder gestreefd naar het nemen van monsters bij de zandmotor, bij Katwijk, bij Castricum/Heemkerk om overlap te hebben met de bemonsteringen in 2017 en de huidige strandbemonstering. Het streven is ook om ter hoogte van de zandmotor, Katwijk en Castricum een raai loodrecht op de kust uit te voeren naar dieper water om te zien of de juveniele vissen ook voorkomen in dieper water. Dit heeft echter een lagere prioriteit dan de kustlangse bemonstering.

Het kustlangs monitoren in juni zal een ruimtelijk beeld generen van de aantallen juveniele vis op dat moment. Dit is relevant om inzicht te krijgen in hoe de jonge vis verspreidt zit langs de kust en of dit te relateren is aan lokale omgevingsvariabelen, met name sediment korrelgrootte. De verzamelde gegevens zullen daarom nog veel waardevoller worden, als dezelfde bemonstering in meerdere jaren uitgevoerd wordt, zodat eventuele consistenties in ruimtelijke verspreidingspatronen ontdekt kunnen worden. 
Dit jaar zal een van Veen happer gebruikt worden voor het monsteren van sediment vanwege de kortere verwerkingstijd van de (kleinere) monsters en flexibelere inzet van deze happer t.o.v. de boxcore die in voorgaande surveys werd gebruikt. Door gebruik te maken van deze happer zullen er meer locaties bemonsterd kunnen worden. Het met de happer verzamelde sediment zal gebruikt worden voor de habitatmodellering op basis van sediment gegevens (korrelgrootte).

De monsters van de van Veen happer worden uitsluitend gebruikt voor het sediment. Het verzamelen van gegevens m.b.t. infauna is geen onderdeel van dit meetplan. De relatie tussen de infauna en de visgemeenschap lijkt op basis van de 2017/2018 gegevens moeilijk tot niet te maken. En met de huidige bemonsteringsstrategie lijkt er weinig toegevoegde waarde te zijn voor de benthos habitatmodellering welke door Deltares wordt uitgevoerd. Daarnaast blijkt de tijd voor het verwerken van de zeer bewerkelijke benthosmonsters uit de kustzone hoger dan ingeschat. Daardoor zijn de kosten voor het verwerken van de benthosmonsters der mate hoge dat dit niet opweegt tegen de beperkte toegevoegde waarde in de geplande analyses.

Tijdens de eerdere bemonsteringen in 2017 en 2018 is er geprobeerd om stereocamera opnames van de bodemstructuur te maken voor een betere karakterisering van de habitat. De resultaten uit 2017 waren beperkt en in 2018 is dit om technische redenen helemaal niet gelukt. Er kleeft dus een groot risico aan het uitvoeren hiervan, en de toegevoegde waarde is tot nu toe beperkt. Daarnaast beperkten de stereocameraopnames het aantal uit te voeren visstations. Zodoende zijn er in dit meetplan geen stereocamera opnames meer opgenomen. Ook werden er akoestische gegevens verzameld in 2017 en 2018 voor pelagische vis. De resultaten hiervan en worden apart gerapporteerd. Het ontbreken van de technische mogelijkheid om pelagisch te kunnen vissen, maakt het echter niet mogelijk om de resultaten aan soorten te koppelen en dit creëert onzekerheid rondom de observaties. Het verzamelen van akoestische gegevens tijdens de nieuwe opzet in 2019 lijkt weinig te kunnen toevoegen aan de resultaten uit eerdere jaren en heeft zonder koppeling met soorten geen toegevoegde waarde. Het verzamelen van gegevens voor pelagische vis is daarmee ook geschrapt. Aangezien er geen gegevens verzameld worden voor pelagische vis, heeft het verzamelen van gegevens van hun voedsel met behulp van het WP2 ook geen toegevoegde waarde.

De vragen die met dit onderdeel beantwoord kunnen worden zijn:

1) In welke mate wordt de 5-6 m diepe kustzone gebruikt door juveniele vis.

2) Zijn eventuele ruimtelijke verschillen in het gebruik van de 5-6m diepe kustzone te verklaren aan de hand van biotische en abiotische omgevingsfactoren?

Natuurlijk kan (en zal) de verspreiding van jonge vis sterk van jaar op jaar kunnen variëren. Voortzetting van dit programma over meerdere jaren is dan eigenlijk ook nodig. Bij een voortzetting over meerdere jaren is het wellicht mogelijk om consistent hogere dichtheden te linken aan de lokale omgevingsvariabelen, dan wel aan de nabij gelegen ondiepere gebieden.

\subsection{Randvoorwaarden}

\section{Vergunningen}

Voor het verzamelen van materiaal van vissen (zoals weefselmonsters) is een ontheffing nodig onder de Wet op Dierproeven omdat vissen gewervelde dieren zijn. Een projectplan is ingediend voor de 2017 survey met een langere looptijd. Hiervoor moet jaarlijks een vernieuwd proefplan ingediend worden, deze is opgesteld en ingediend op 11 maart 2019. En op 21 maart is de goedkeuring verkregen, onder het proefplannummer 2017.D-0005.003.

\section{Weersgevoeligheid}

Voor de uitvoer van de bemonstering is goed weer (weinig wind en beperkte golfhoogte) nodig. Het risico bestaat dat de bemonstering op sommige dagen niet volledig uitgevoerd kan worden. Bij een golfhoogte boven de $1 \mathrm{~m}$ kan de Luctor eigenlijk geen werkzaamheden uitvoeren. Bij lagere golfhoogte zal er ter plekke beoordeeld moeten worden of uitvoering mogelijk is onder invloed van de lokale condities. 


\section{$2 \quad$ Methode}

\section{$2.1 \quad$ Meetstrategie}

\subsubsection{Doelsoorten vis}

De doelsoorten zijn schol, tong, griet en tarbot. Deze platvissoorten liggen op of graven zich in het sediment en zijn daarmee afhankelijk van het type sediment. Dit sediment wordt mogelijk veranderd door de geplande zandsuppleties, wat dan een direct effect op deze soorten zou kunnen hebben. De focus van de bemonstering ligt op juveniele platvis en in het bijzonder op de 0-groep platvis (vis in hun eerste levensjaar). De lengte van 0 -groep juveniele platvis verschilt tussen soorten en verandert in de tijd. In juni is naar verwachting de lengterange van 0-groep juvenielen van de doelsoorten 3-15 $\mathrm{cm}$. Daarom zal de bemonstering plaats vinden met een $3 \mathrm{~m}$ boomkor waarbij een kleine maaswijdte (1 cm gestrekt) in de kuil gehanteerd wordt.

Naast de doelsoorten zullen ook de overige vis en macrobenthos soorten welke gevangen worden geregistreerd worden. Ook voor deze soorten is het eventueel mogelijk een beeld over de verspreiding langs de Nederlandse kust te creëren.

\subsubsection{Temporele dekking}

De Luctor is beschikbaar in de week van 17 tot 21 juni 2019, de daaropvolgende week is het schip nog beschikbaar om terug te keren naar de thuishaven. Hiermee zijn dus 5 volledige dagen beschikbaar voor de bemonstering, waarvan vrijdag waarschijnlijk alleen deels beschikbaar is voor bemonsteren, omdat de bemanning in de middag al van boord gaat om nog op tijd thuis te kunnen.

\subsubsection{Ruimtelijke dekking}

De gewenste ruimtelijke dekking is het bemonsteren van de Nederlandse kustzone van de Maasvlakte tot aan Texel in de dieptezone 5-6m, eventueel met een aantal raaien naar dieper water. De periode van een week is echter beperkend om dit volledige gebied te kunnen bestrijken, daarnaast is het noodzakelijk dat de Luctor op het eind van iedere dag een geschikte haven kan bereiken.

De thuishaven van de Luctor is Yerseke, maar er zou vertrokken kunnen worden vanuit Stellendam. Op de eerste dag zou het gebied vanaf Hoek van Holland tot iets voorbij Scheveningen bestreken kunnen worden, waarbij het in eerdere jaren bemonsterde gebied van de zandmotor bemonsterd wordt.

De tweede dag kan er dan vanuit Scheveningen tot aan IJmuiden bemonsterd worden, waarbij er overlap is met het gebied bij Katwijk waar de strandbemonstering uitgevoerd wordt.

De derde dag zou er dan ten zuiden en noorden van IJmuiden bemonsterd kunnen worden, waarbij er overlap is met het gebied bij Castricum waar de strandbemonstering uitgevoerd wordt.

De vierde dag kan dan gebruikt worden om op weg naar Den Helder nog monsters te nemen, waarna op de vijfde dag in de omgeving van Den Helder bemonsterd kan worden.

Dit alles is erg afhankelijk van de weersomstandigheden, waarbij een dag met mindere condities ervoor kan zorgen dat het gebied rond Den Helder helemaal niet bemonsterd wordt, en twee slechte dagen ervoor kan zorgen dat er niet verder dan IJmuiden bemonsterd wordt, etc. 


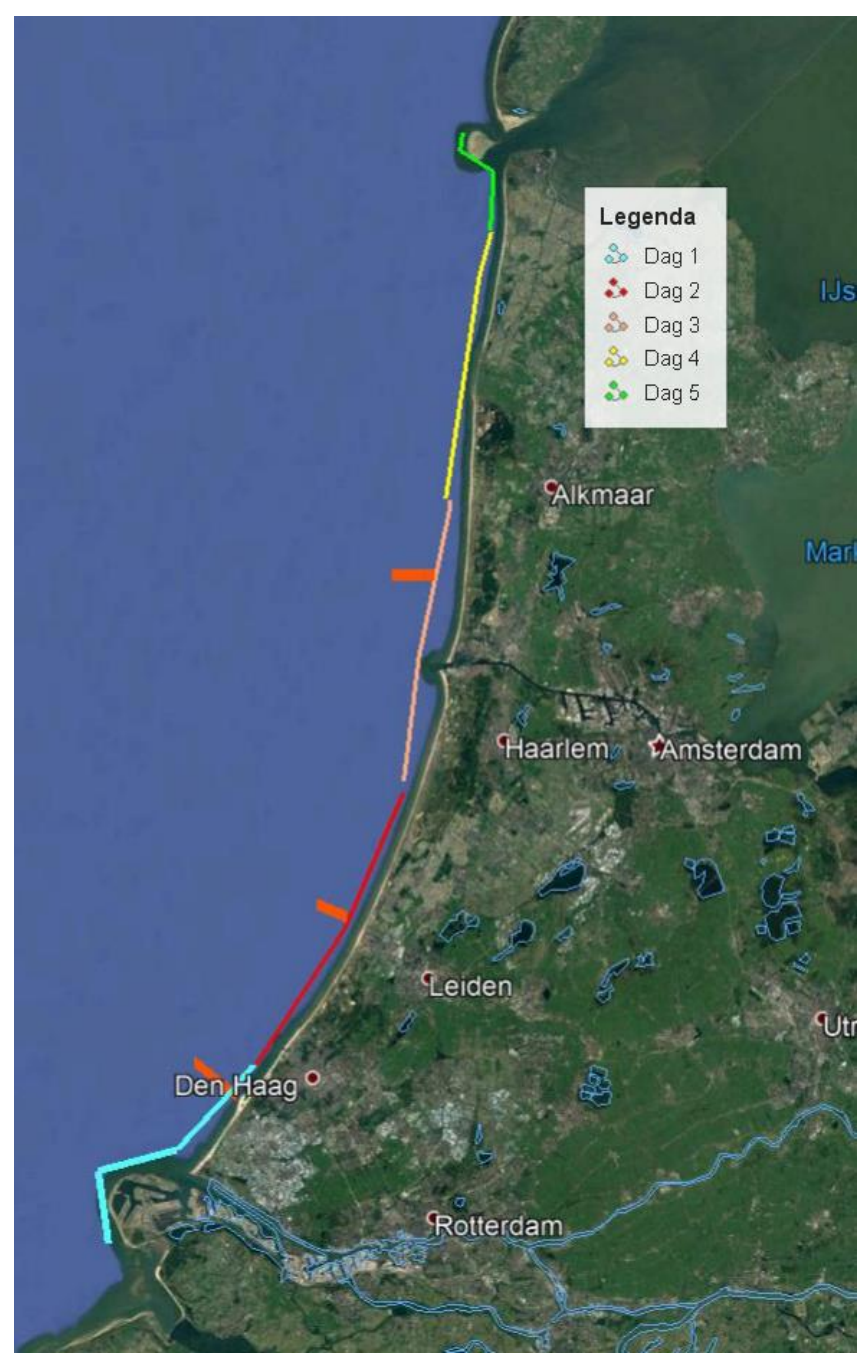

Figuur 1. Ruwe verdeling van de dagen over het gewenste onderzoeksgebied.

De inschatting is dat er per dag afhankelijk van de vaarafstanden ongeveer 15-20 locaties bemonsterd kunnen worden. In het totaal komt dit uit op 75-100 locaties verspreid langs de Nederlandse kust.

\subsubsection{Biotische en abiotische habitatvariabelen}

Om verschillen in de verspreiding van juveniele demersale vis eventueel te kunnen verklaren, worden er verschillende habitatvariabelen bepaald. Omdat de focus van dit onderzoek ligt op het verkrijgen van een ruimtelijk beeld van de verspreiding, worden alleen de habitatvariabelen bepaald die beperkte tijd kosten om uit te voeren. Dit in tegenstelling tot de bemonsteringen in afgelopen twee jaar waarbij habitatkarakterisering van de ondiepe vooroever op zich ook een doel vormde.

De variabelen die gemeten gaan worden zijn:

- $\quad$ Sediment (korrelgroottesamenstelling)

- Waterdiepte (op startpunt en eindpunt van iedere vistrek)

- Zeewatertemperatuur

- $\quad$ Saliniteit

- Troebelheid/ Zichtdiepte

\subsubsection{Bemonsteringsinstrumenten}

\section{Vis}

Demersale vis wordt bemonsterd met een $3 \mathrm{~m}$ boomkor (het DFS-tuig). Dit tuig heeft één wekker en een klossenpees. De maaswijdte in de kuil is normaliter $2 \mathrm{~cm}$ gestrekt, maar voor dit onderzoek wordt net als in 2017 en 2018 een fijnmazige binnenkuil geplaatst van $1 \mathrm{~cm}$ gestrekt. 


\section{Sediment}

Sediment wordt bemonsterd een kleine van Veen happer. Uit de hap wordt met een steekbuisje van $26 \mathrm{~mm}$ diameter een core genomen voor de analyse van het sediment. De sediment monsters worden extern geanalyseerd.

\section{Zoutgehalte, watertemperatuur, diepte en troebelheid / doorzicht}

Er zal een CTD worden bevestigd op de $3 \mathrm{~m}$ boomkor. Deze CTD meet standaard conductiviteit (proxy voor saliniteit), watertemperatuur en druk (diepte). Daarnaast zal een extra sensor voor turbiditeit (troebelheid) toegevoegd worden aan de CTD.

Met een Secchi-schijf worden metingen van zichtdiepte gedaan vanaf de Luctor. Turbiditeit en zichtdiepte zijn niet recht evenredig met elkaar en de relatie tussen beide parameters verschilt afhankelijk van waterkwaliteitsparameters (zoals saliniteit). Derhalve geven de Secchi-schijf metingen extra informatie, ondanks dat dit een vrij grove meettechniek is.

\section{DNA-barcodering}

Aansluitend bij het dieetwerk dat mogelijk uitgevoerd wordt tijdens de strandbemonstering, zal ook tijdens de Luctor bemonstering platvis verzameld worden waarvan met DNA-methodes het dieet bepaald zal worden. Voor het uitvoeren van DNA-analyses op de prooiresten in de magen van juveniele platvis, zullen deze verzameld en in $96 \%$ ethanol gepreserveerd worden. Afhankelijk van de vangst, zal dit gedaan worden voor een of meer van de doelsoorten (zie 2.1.1) en voor een of meerdere lengte-klassen.

De invulling van het werk aan DNA-barcodering van prooiresten in de magen van juveniele platvissen is nog niet uitgekristalliseerd. We gaan hierbij samenwerken met het lab van Animal Breeding en Genetics $(A B \& G)$ van Wageningen Universiteit en werken hiervoor samen met Reindert Nijland. De insteek is om het werk uit te laten voeren door een MSc student om de kosten te minimaliseren. De student zal gezamenlijk door onderzoekers van AB\&G en WMR begeleid worden. De keuze welke soort(en) en hoeveel monsters er geanalyseerd worden is nog niet vastgelegd.

\subsection{Meetplan}

\subsubsection{Visbemonstering}

De dagelijkse transecten zoals ingedeeld in figuur 1, zijn voor de eerste 4 dagen hemelsbreed tussen de 30-35 km. Het transect voor de laatste dag is korter. De inschatting is dat bij goede weersomstandigheden het bemonsteren van 15-20 locaties haalbaar moet zijn. Dit betekent dat er om de $1,5-1,75 \mathrm{~km}$ gevist zou kunnen worden. In de praktijk zal dit vanwege nautische aspecten niet geheel uitvoerbaar zijn, maar er zal wel naar gestreefd worden.

Wanneer de tijd het toelaat zal er ter hoogte van de zandmotor, van Katwijk aan Zee en het strand van Castricum een raai naar dieper water worden bemonsterd. Waarbij tussen de diepte van 10-20 m vier vistrekken uitgevoerd gaan worden. Deze vistrekken zijn bedoeld om een inschatting te krijgen of de juveniele platvis in het diepere water voorkomt. Deze drie locaties zijn gekozen om aan te sluiten bij de eerdere bemonsteringen in 2017 en de huidige strandbemonstering 2019. Echter, per locatie is het niet direct van belang waar deze raaien naar dieper water uitgevoerd worden. Als de tijd het toelaat kunnen deze ook een op willekeurige andere plek uitgevoerd worden.

\subsubsection{Vangstverwerking}

De vangstverwerking gebeurt volgens de protocollen opgesteld in het handboek bestandsopnamen (van Damme e.a., 2019), met de volgende aanpassingen:

- trekduur: 5 min

- maaswijdte kuil: $1 \mathrm{~cm}$ gestrekt

- alle vissoorten (soms groepen van soorten): lengtemetingen op de mm nauwkeurig

- alleen doelsoorten (zie 2.1): lengte gestratificeerd deelmonster samenstellen voor individuele gewichten $(0,1 \mathrm{~g}$ nauwkeurig) 
- zandspieringen (Ammodytes tobianus en A. marinus) worden aan boord gedetermineerd, ter controle wordt een random deelmonster meegenomen naar het lab.

Alle vissen en garnalen worden aan boord gedetermineerd tot op soortniveau (met enkele uitzonderingen zoals de grondels van het geslacht Pomatoschistus die naar het lab gaan voor determinatie) en gemeten ( $\mathrm{mm}$ nauwkeurig). Dichtheden $(\mathrm{n} / \mathrm{ha}$ ) worden berekend uit de aantallen per trek, de afgelegde afstand binnen een trek en de breedte van het vistuig. Benthossoorten worden ook voor zover mogelijk uitgezocht tot op soortniveau en vervolgens geteld.

Voor de doelsoorten (schol, tong, griet en tarbot) worden - in een deelmonster - individuele lengtes en gewichten bepaald en eventueel weefselmonsters genomen. Voor dieetanalyse worden per dag van minstens 2 locaties 10 vissen per soort per locatie opgeslagen in een potje met 96\% ethanol voor dieet bepaling op basis van DNA-barcodering van de prooiresten in de maaginhoud. Deze platvissen worden eerst gedood door met een scalpel een snede in de kop te maken, ze mogen per locatie per vistrek gezamenlijk worden opgeslagen in de pot. In de pot wordt een water/alcohol bestendig briefje (magenbriefje) met datum, locatie en sample-ID gestopt, deze gegevens worden ook op de pot geschreven.

\subsubsection{CTD}

Er zal een datalogger CTD voorzien van turbidity sensor bevestigd worden op de $3 \mathrm{~m}$ boomkor (Luctor), welke continue zal meten. Daarmee zijn er CTD (Conductivity, Temperature, Depth) en turbidity (troebelheid) gegevens die gepaard gaan met de vismonsters. Deze apparaten worden geïnstalleerd door deskundige technici. De installatie en bediening wordt gedaan volgens de handleidingen van de betreffende apparaten.

\subsubsection{Secchi}

Vóór elke vistrek wordt een Secchi-schijf meting vanaf de Luctor uitgevoerd. De Secchi-schijf wordt te water gelaten aan de schaduwzijde van het schip tot een waterdiepte waarop de schijf niet meer zichtbaar is. Vervolgens wordt de schijf langzaam opgehaald, totdat deze weer zichtbaar is. Deze waterdiepte wordt genoteerd als Secchi-diepte op 0,25 m nauwkeurig. Bij golfslag wordt de schijf gehouden op een diepte waarop deze beurtelings wel en niet zichtbaar is en wordt de gemiddelde waterdiepte op 0,25 m nauwkeurig genoteerd. Indien de tijd het toelaat kan een 2e meting door een ze persoon uitgevoerd worden. De Secchi-diepte is dan de gemiddelde van de twee waarnemingen.

\subsubsection{Sediment bemonstering}

Op iedere locatie zal na het vissen met een kleine van Veen happer een sedimentmonster genomen worden. Met de happer wordt een representatieve hap genomen, waarvan tenminste de bovenste 10 $\mathrm{cm}$ intact is. Als dit niet goed gaat wordt het tot 3 keer op nagenoeg dezelfde locatie geprobeerd, daarna wordt dit nog 3 keer geprobeerd op een andere locatie op de beviste vislijn. Uit een goede hap wordt met een steekbuisje (26 mm diameter) sediment genomen, dit monster wordt ingevroren met vermelding van datum, locatie en sample-ID. De rest van de hap wordt over boord gezet.

\subsubsection{Personele inzet}

Voor zowel het veldwerk als het laboratoriumwerk zullen deskundigen ingezet worden. De personen die ingezet worden voor het veldwerk, inclusief hun gebied van expertise wordt gegeven in Tabel 1.

Tabel 1 Personele bezetting veldwerk

\begin{tabular}{|l|l|l|}
\hline $\begin{array}{l}\text { week } \\
17-21 \text { juni }\end{array}$ & $\begin{array}{l}\text { Visbemonstering, CTD } \\
\text { André Dijkman }\end{array}$ & $\begin{array}{l}\text { vis, benthos en sedimentbemonstering } \\
\text { Maarten van Hoppe }\end{array}$ \\
\hline
\end{tabular}


De korrelgrootte-analyses van de sedimentmonsters worden uitbesteed aan een extern laboratorium, waarschijnlijk het NIOZ.

\subsubsection{Databeheer en -management}

De resultaten van de visbemonsteringen worden aan boord in het WMR-invoersysteem Billie Turf ingevoerd, wat de kans op typfouten verkleint. Na afloop van de survey worden hier ook gegevens over oppervlakte en bodem watertemperatuur en saliniteit aan toegevoegd op basis van de CTDgegevens.

De in Billie Turf ingevoerde gegevens worden gecheckt volgens standaardprocedure op allerlei mogelijke fouten (posities, lengte-gewicht relaties, max en minimale lengtes etc.) alvorens ze in de database van WMR geïmporteerd worden. Waarin ze permanent opgeslagen en beschikbaar blijven in het standaard format van de WMR vis- en benthosdata.

Vanuit de WMR-database worden de gegevens getransformeerd en omgezet in AQUO-standaard. In dit format worden de gegevens via de Wageningen Marine Research Geoserver als URL geleverd aan Informatie Huis Marien en Water Info Extra zodat op deze wijze de data via deze websites online beschikbaar worden gesteld, waarbij de opslag dus plaats vindt bij WMR. 


\section{$3 \quad$ Kwaliteitsborging}

Wageningen Marine Research beschikt over een ISO 9001:2015 gecertificeerd kwaliteitsmanagementsysteem. Dit certificaat is geldig tot 15 december 2021. De organisatie is gecertificeerd sinds 27 februari 2001. De certificering is uitgevoerd door DNV GL.

De visbemonstering en opslag van visdata gebeurt volgens de protocollen opgesteld in het handboek bestandsopnamen (van Damme e.a., 2019).

Het veldwerk wordt uitgevoerd door ervaren veldmedewerkers die een goede kennis hebben van de aanwezige soorten. Deze kennis wordt jaarlijks intern getoetst. Er worden protocollen gevolgd die ervoor zorgen dat de werkzaamheden op consistente wijze worden uitgevoerd.

De resultaten van de visbemonsteringen worden aan boord in het WMR-invoersysteem Billie Turf ingevoerd, wat de kans op typfouten verkleint. In Billie Turf ingevoerde gegevens worden gecheckt volgens standaardprocedure op allerlei mogelijke fouten (posities, lengte-gewicht relaties, max en minimale lengtes etc.) alvorens ze in de database van WMR geïmporteerd worden.

Kwaliteitsborging op het veldwerk vindt plaats volgens het eigen kwaliteitssysteem van Wageningen Marine Research. Ook kent WMR een eigen kwaliteitssysteem voor de opslag van data.

Kwaliteitsborging van de data wordt door Wageningen Marine Research en Deltares ook getoetst aan het op te stellen dataplan van Ecologisch Gericht Suppleren II. RWS (Joan Staeb) zal nagaan of de data voldoende aansluiten bij de RWS-portalen.

Bovenstaande controles staan beschreven in Wageningen Marine Research werkvoorschrift ISW 2.10.2.105.

Indien sprake is van onbeheerste kwaliteit worden passende maatregelen genomen. 


\section{Literatuur}

Baptist, M., L. Bolle, B. Couperus, I. Tulp en R. v. Hal (2017) Ecologisch Gericht Suppleren: meetplan geïntegreerde ecosysteem survey 2017. Wageningen Marine Research.

Couperus, B., M. Baptist, D. Burggraaf, A. Dijkman-Dulkes, J. Perdon, M. Post en H. Verdaat (2017) Ecologisch gericht suppleren : verslag pilot multi-method survey 2016. Wageningen Marine Research.

Damsma, P., H. Holzhauer, T. Vermaas, B. van de Valk, L. van Duren en A. de Backer (2017) Ecologisch gericht suppleren I, resultaten van het onderzoek.

De Vriend, H. J., M. van Koningsveld, S. G. Aarninkhof, M. B. de Vries en M. J. Baptist (2015) Sustainable hydraulic engineering through building with nature. Journal of Hydro-environment research 9: 159171.

Glorius, S. T., K. van de Wolfshaar en I. Tulp (2012) Abundance patterns of six fish species in the shallow coastal zone in The Netherlands, IMARES report C101/12.

Herman, P., H. Meijer-Holzhauer, S. Vergouwen, J. Wijsman en M. J. Baptist (2016) Ecologische effecten van kustsuppleties; Systeembeschrijving (deel A), onderzoeksprioriteiten (deel B) en ontwerp uitvoeringsplan (deel C). Deltares, 100 pagina's.

Mulder, J. P. M., S. Hommes en E. M. Horstman (2011) Implementation of coastal erosion management in the Netherlands. Ocean \& Coastal Management 54: 888-897.

Teal, L. R. en O. A. van Keeken (2011) The importance of the surf zone for fish and brown shrimp in The Netherlands IJmuiden : IMARES, (Report C054/11) - p. 80.

Temmerman, S., P. Meire, T. J. Bouma, P. M. Herman, T. Ysebaert en H. J. de Vriend (2013) Ecosystembased coastal defence in the face of global change. Nature 504: 79-83.

Van Dalfsen, J. A., H. Holzhauer en E. Verduin (2014) Veldverslag bemonstering Ameland \& Schiermonnikoog $4 \& 5$ augustus 2014. Delft, Deltares.

van Damme, C., L. Bolle, I. de Boois, D. Burggraaf, B. Couperus, R. van Hal en T. Pasterkamp (2019) Handboek en protocollen voor bestandsopnamen en routinematige bemonsteringen op zee en in estuaria. CVO, CVO rapport 19.001.

van de Wolfshaar, K., S. T. Glorius en M. T. van der Sluis (2012) Habitat suitability rules for the shallow coastal zone in The Netherlands, IMARES report C064/12.

van der Geest, M., I. Tulp en R. van Hal (2019) Ecologisch Gericht Suppleren: Meetplan strandsurvey 2019. Wageningen Marine Researcg, C045/19, 26 pagina's.

van Hal, R., B. Couperus, A. Dijkman-Dulkes en M. Baptist (2017) Reisverslag kustsurvey EGSII : Juni-juli 2017. Wageningen Marine Research.

van Hal, R. en A. Dijkman Dulkes (2018) Reisverslag kustsurvey EGSII : Juni 2018. Wageningen Marine Research.

Van Slobbe, E., H. J. de Vriend, S. Aarninkhof, K. Lulofs, M. B. de Vries en D. P. (2013) Building with Nature: in search of resilient storm surge protection strategies. Natural hazards 66: 1461-1480. 


\section{Verantwoording}

Rapport C052/19

Projectnummer: 4312100053

Dit rapport is met grote zorgvuldigheid tot stand gekomen. De wetenschappelijke kwaliteit is intern getoetst door een collega-onderzoeker en het verantwoordelijk lid van het managementteam van Wageningen Marine Research

Akkoord:

Matthijs van der Geest

Onderzoeker Mariene Ecologie

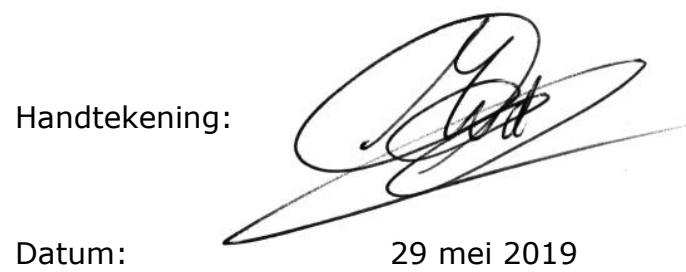

Akkoord:

Jakob Asjes

Manager Integratie

Handtekening:

Datum:

29 mei 2019 
Wageningen Marine Research

T: $+31(0) 317480900$

E: marine-research@wur.nl

www.wur.nl/marine-research

Bezoekers adres:

- Ankerpark 271781 AG Den Helder

- Korringaweg 7, 4401 NT Yerseke

- Haringkade 1, 1976 CP IJmuiden
Wageningen Marine Research levert met kennis, onafhankelijk wetenschappelijk onderzoek en advies een wezenlijke bijdrage aan een duurzamer, zorgvuldiger beheer, gebruik en bescherming van de natuurlijke rijkdommen in zee-, kust- en zoetwatergebieden.
Wageningen Marine Research is onderdeel van Wageningen University \& Research. Wageningen University \& Research is het samenwerkingsverband tussen Wageningen University en Stichting Wageningen Research en heeft als missie: 'To explore the potential of nature to improve the quality of life' 